\title{
Irfani
}

\section{EKSISTENSI PENYULUH AGAMA ISLAM DALAM MENANGKAL FAHAM RADIKALISME DI KECAMATAN SUWAWA TIMUR KABUPATEN BONE BOLANGO}

\author{
Ramli Liputo \\ Kepala Kantor Urusan Agama di Kecamatan Suwawa Timur Kabupaten Bone Bolango
}

\begin{abstract}
ABSTRAK
Studi ini mencoba melakukan telaah analisa terhadap keberadaan penyuluh agama Islam dalam upaya untuk menangkal faham radikalisme. Penyuluh agama Islam merupakan salah satu komponen yang memiliki peran sangat urgen di Kementerian Agama. Baik secara teknis maupun secara personal keberadaan mereka sangat tepat dalam rangka menangkal faham radikalisme, melalui strategi penyuluhan atau dakwah, hal ini dimungkinkan karena aktivitas mereka langsung bersosialisasi dengan kehidupan masyarakat. Dalam kaitan dengan faham radikalisme memang di Kecamatan Suwawa Timur Kabupaten Bone Bolango belum ada satupun isu tentang adanya faham radikalisme, akan tetapi potensi ke arah itu bisa saja terjadi, jika kemudian tidak dilakukan pencegahan sejak dini. Peran pencegahan inilah yang kemudian membutuhkan pemahaman dasar dalam beragama sehingga tidak terpapar oleh faham radikalisme. Untuk maksud tersebut, maka telaah ini didasarkan pada pokok permasalahan yakni: 1) Bagaimana kegiatan penyuluh agama Islam dalam menangkal faham radikalisme di Kecamatan Suwawa Timur Kabupaten Bone Bolango, 2) Kendala dan Solusi dihadapi apa dalam melakukan penyuluhan menangkal faham radikalisme di Kecamatan Suwawa Timur Kabupaten Bone Bolango, 3) Bagaimana tanggapan masyarakat Kecamatan Suwawa Timur terhadap upaya penyuluhan dalam menangkal faham radikalisme.

Hasil penelitian menunjukkan adanya kegiatan dan gerakan yang dilakukan secara positif oleh para penyuluh agama Islam di Kecamatan Suwawa Timur Kabupaten Bone Bolango, dengan gerakan dakwah yang memanfaatkan potensi keagamaan di masingmasing desa serta kerjasama dengan pemerintah desa. Kendalanya adalah kehidupan sosial masyarakat yang beragam untuk memenuhi kebutuhan hidup sehari-hari, solusinya adalah memacu semangat dan kesadaran para penyuluh agama Islam dengan rasa tanggungjawab yang tinggi dalam melakoni tugas yang diamanahkan kepada mereka. Dengan itu semua maka gerakan dakwah melalui pemanfaatan seluruh potensi masyarakat di Kecamatan Suwawa Timur Kabupaten Bone Bolango terus dilakukan secara dinamis dan berkelanjutan. Hal ini mengindikasikan bahwa penyuluh agama Islam di Kecamatan Suwawa Timur Kabupaten Bone Bolango terus eksis dengan gerakan bimbingan dan penyuluhannya.
\end{abstract}

Kata Kunci: Penyuluh Agama Islam, Faham Radikalisme 


\section{Irfani}

ISSN 1907-0969 E ISSN 2442-8272

Volume 15 Nomor 2 Desember 2019

Halaman 84-98

http://journal.iaingorontalo.ac.id/index.php/ir

\section{PENDAHULUAN}

Agama Islam merupakan agama yang rahmatan lil 'alamiin, artinya keberadaan ajaran Islam sebagai agama wahyu tersebut, memiliki peran penting untuk penyelematan ummat di dunia dan akhirat kelak, tanpa melihat klaster ummat secara individual atau kelompok, baik dari sisi ritual keagamaan apalagi kehidupan ekonomi. Betapa tidak nilainilai ajaran yang dibawah oleh Rasulullah Muhammad SAW., tersebut membumi ketika itu hanya disyiarkan dengan kesantunan dan akhlakul karimah yang dicontohkan langsung oleh Rasulullah saat berdakwah.

Dewasa ini ajaran Islam yang cinta akan kedamain dan keselamatan itu dicederai oleh kelompok-kelompok yang berafiliasi dengan aliran-aliran garis keras atau yang lebih trend dikenal dengan aliran radikal. Munculnya paham radikalisme tersebut memicu benturan-benturan antar sesama pemeluk ajaran Islam, bahkan saling mengkafirkan antar kelompok. Bukan hanya itu, kelompok-kelompok radikalis ini tidak segan-segan melakukan tindak pembunuhan terhadap orang-orang atau kelompok yang tidak sepaham dengan mereka.

Tindakan-tindakan radikal yang dilakukan oleh sekelompok penganut ajaran Islam tersebut kemudian menjustifikasi dan mengeralisasi agama Islam, bahwa seolaholah Islam merupakan ajaran radikal. Fenomena tersebut kemudian menyadarkan para kaum cendekiawan muslim dan para ulama termasuk Kementerian Agama untuk menggiatkan pembinaan dan penyuluhan kepada masyarakat muslim tetang pencegahan berkembangnya paham radikalisme di tengah-tengah masyarakat.

Salah satu garda terdepan yang dimiliki oleh Kementerian Agama dalam hal menangkal paham radikal di kalangan masyarakat muslim adalah mereka para penyuluh agama Islam. Eksistensi mereka sangat dibutuhkan karena mereka berada dan berkecimpung langsung di tengah-tengah masyarakat. Mereka para penyuluh agama Islam sangat mengerti tentang kondisi masyarakat yang dihadapinya, tertuama dalam rangka memilih cara yang paling tepat untuk melakukan penyuluhan kaitan dengan persoalan-persoalan etika keberagamaan.

Penyuluh agama Islam merupakan salah satu profesi fungsional di Kementerian Agama, tugas pokonya adalah memberikan penyuluhan atau menjadi pendakwah di lingkungan masyarakat tertentu yang menjadi wilayah binaannya. Oleh Kementerian Agama mereka diberikan insentif dalam rangka menunjang kerja-kerja mereka agar kegiatan penyuluhan dapat memberikan hasil yang lebih baik, tentang pemahaman masyarakat tentang etika keberagamaan. Dalam menjalankan misi dakwahnya tersebut, maka salah satu materi dalam muatan dakwahnya adalah upaya untuk mencegah penyebaran paham-paham radikalisme. Berdakwah merupana salah satu strategis yang sampai dengan saat ini cukup mudah dan terus dilaksanakan oleh para penyuluh agama Islam dalam menangkal berbagai isu radikalisme di kalangan umat muslim.

Kabupaten Bone Bolango tepatnya di Kecamatan Suwawa Timur, eksistesi para penyuluh sangat dibutuhkan oleh masyarakat muslim yang terbagi ke dalam 9 Desa. Kodisi kehidupan masyarakatnya yang masih rata-rata menengah kebawah dalam hal pemahaman etika keberagamaan sangat berpotensi untuk dimasuki oleh paham-paham 


\section{Irfani}

ISSN 1907-0969 E ISSN 2442-8272

Volume 15 Nomor 2 Desember 2019

Halaman 84-98

http://journal.iaingorontalo.ac.id/index.php/ir

radikalisme. Hal ini tentunya memerlukan penyuluhan-penyuluhan tentang konsep dasar keagamaan sehingga warga terus terhindar dari paham-paham yang menyesatkan.

Harapannya adalah kehadiran 9 orang tenaga penyuluh di bawah koordinasi Kantor Urusan Agama Kecamatan Suwawa Timur itu, dapat menjadi pilar dan ujung tombak tentang tegaknya syi'ar Islam. Kendatipun demikian dengan kondisi masyarakat yang heterogen baik dari sisi tingkat pemahaman terhadap ajaran Islam serta kehidupan sosial ekonomi yang beragam, tentu membutuhkan pendekatan yang strategi sehingga upaya-upaya penyuluhan yang digalakkan dapat efektif dan efisien dalam mencegah masuknya aliran-aliran sempalan yang berujung pada radikalisme.

Melihat kondisi seperti ini maka penulis mencoba menggali informasi melalui penelitian ini perihal "Eksistensi Penyuluh Agama Islam dalam Menangkal Paham Radikalisme di Kecamatan Suwawa Timur Kabupaten Bone Bolango". Dengan beberapa rumusan masalah pokok yakni : 1) Bagaimana kegiatan penyuluh agama Islam dalam menangkal faham radikalisme di Kecamatan Suwawa Timur Kabupaten Bone Bolango, 2) Kendala apa saja yang dihadapi dalam melakukan penyuluhan menangkal faham radikalisme di Kecamatan Suwawa Timur Kabupaten Bone Bolango, 3) Bagaimana tanggapan masyarakat Kecamatan Suwawa Timur terhadap upaya penyuluhan dalam menangkal faham radikalisme.

\section{KAJIAN PUSTAKA}

\section{Penyuluh Agama Islam Tugas dan Fungsi}

Upaya dari berbagai kaum cendekiawan muslim untuk terus membumikan ajaran Islam dengan berbagai metode dan pendekatan terus menjadi perhatian. Baik melalui berbagai media cetak, maupun tindakan langsung bersentuhan dengan masyarakat. Salah satu tindakan nyata yang dilakukan oleh pemerintah dalam hal ini melalui Kementerian Agama, adalah dengan mengangkat para tenaga penyuluh agama Islam yang kemudian oleh Kementerian Agama di beri tugas untuk melakukan penyulahan langsung di tengahtengah masyarakat.

1. Siapa Sebenarnya Penyuluh Agama Islam

Penyuluh agama Islam dalam terminologi secara umum merupakan orang yang memiliki kemampuan pengetahuan ajaran agama Islam yang memadai dan diberi tugas untuk memberikan penyuluhan kepada masyarakat tentang hal-hal yang berkaitan dengan konsep dasar ajaran Islam, dengan harapan agar masyarakat dapat memahami dan mengamalkan ajaran agama Islam dengan baik dan benar. Sebagai bentuk perhatian pemerintah akan pentingnya penyuluhan ajaran Islam kepada masyarakat muslim, maka melalui Kementerian Agama penyuluh agama Islam diangkat sebagai bagian dari Aparatur Sipil Negara (ASN) meskipun ada yang berstatur Pegawai Negeri Sipil dan Penyuluh Non PNS. Kendatipun demikian tanpa melihat status tersebut bahwa tugastugas penyluh agama Islam terus dimaksimalkan. Siapa penyuluh Agama Islam, maka berdasarkan rujukan regulasi yang mengaturnya terutama dalam beberapa kebijakan menteri agama menyebutkan bahwa Penyuluh Agama Islam adalah orang melaksanakan tugas sebagai pendorong, penyemangat, penggerak maupun penyemarak setiap kegiatan yang tumbuh di tengah-tengah masyarakat, menuju pada keteraturan dan kelanggengan 


\section{Irfani}

ISSN 1907-0969 E ISSN 2442-8272

Volume 15 Nomor 2 Desember 2019

Halaman 84-98

http://journal.iaingorontalo.ac.id/index.php/ir

hidup, guna terwujudnya kemajuan dalam kehidupan menuju masyarakat yang sejahtera dunia dan akhirat yang peada gilirannya akan menciptakan ketenangan dan kedamaian sebagaimana mana yang dikandung oleh Islam yang menjadi rahmat bagi semesta alam. ${ }^{1}$

Dalam pengertian tersebut maka penyuluh agama Islam memiliki peran dan tanggungjawab dalam rangka memberikan pemahaman mendasar tentang ajaran agama Islam, sebagai landasan bagi mereka dalam menata etika kehidupan yang dilandasi oleh nilai-nilai ajaran Islam. Menelisik makna tersebut tentunya hal ini menjadi sesuatu yang sangat menarik untuk dibahas, apakah kemudian peran penyuluh agama Islam itu benarbenar telah sesuai dengan realitas sosial saat ini. Kendatipun secara umum dapat dikatakan bahwa eksistensi penyuluh agama Islam telah memberi warna dalam tegaknya syari'at Islam ditengah masyarakat, akan tetapi benarkah fakta tersebut karena peran aktif para penyuluh agama Islam, atau jangan-jangan ada peran-peran komunitas dakwah lainnya yang bergerak di tengah-tengah masyarakat. Apapun persepsi yang dimunculkan terkait dengan siapa sesungguhnya penyuluh agama Islam bagi penulis yang paling penting adalah misi mereka yang utama yakni memberikan bimbingan kepada masyarakat muslim tentang berbagai ajaran Islam. Hal ini mengindikasikan bahwa eksistensi mereka benar-benar dibutuhkan dalam rangka membumikan ajaran Islam. Jika dimaknai dalam pendekatan istilah yang digunakan, maka perlu dimaknai dari katan "Penyuluhan merupakan salah satu teknik bimbingan. Sering dikatakan bahwa penyuluhan merupakan inti atau jantung bimbingan. Penyuluhan terutama dugaan untuk membantu mengatasi masalah-masalah psikologis, sosial, spiritual dan moral etis".2

Berdasarkan pendekatan istilah tersebut, maka penyuluh agama Islam adalah orang yang diberi tanggungjawab paling tidak dalam beberapa hal berikut ini:

a. Konseling Islam adalah konseling yang diorentasikan untuk memecahkanmasalah pernikahan dan keluarga, kesehatan mentaldan kesadaran beragama.

b. Proses bantuan yang diberikan kepada individu (baik secara perseoranganmaupun kelompok) agar memperoleg pencerahan diri dalam memahami dan mengamalkan nilai-nilai agama (aqidah, ibadah, dan akhak mulia) melalui uswah hasana (contoh teladan yang baik), pembiasaan atau pelatihan, dialog, dan pemberian informasi yang berlansung sejak usia dini sampai pada usia tua, dalam upaya mencapai kebahagiaan dunia dan akhirat.

c. Proses pemberian bantuan kepada individu agar mampu mengembangkan kesadaran dan komitmen beragamanya ( primodial kemahlukannya yang fitrah adalah tauhidullah) sebagai hamba dan khalifa Allah yang bertanggung jawab untuk mewujudkan kesejatraan kebahaagiaan hidup bersama baik secara fisik (jasmani) maupun psikis (ruhaniah), baik didunia ini maupun di akhirat kelak.

d. Proses pemaknaan diri dalam kebermaknaan sosial. ${ }^{3}$

\footnotetext{
${ }^{1}$ https://gorontalo.kemenag.go.id/artikel/29577/-

${ }^{2}$ Umar dan Sartono, Bimbingan Penyuluhan (Bandung : Pustaka Setia, 1998), h. 15

${ }^{3}$ www. Isna. Net/ library/ paper, 2003
} 


\section{Irfani}

ISSN 1907-0969 E ISSN 2442-8272

Volume 15 Nomor 2 Desember 2019

Halaman 84-98

http://journal.iaingorontalo.ac.id/index.php/ir

Berdasarkan indikator tersebut sangatlah jelas bahwa penyuluh agama Islam adalah mereka yang memiliki tugas dan tanggungjawab dalam memerankan dirinya sebagai tenaga penyuluh yang berkaitan dengan hal-hal ajaran agama Islam, memberikan bimbingan dalam upaya menumbuhkan kesadaran beragama menuju keselamatan dunia dan akhirat.

Dalam kapasitas ketenagaan penyuluh agama Islam di bawah kendali Kementerian Agama baik yang diangkat dengan status Pegawai Negeri Sipil maupun tenaga penyuluh honorer. Meskipun dalam status yang berbeda akan tetapi tugas dan tanggungjawab sebagai penyuluh agama Islam tetap sesuai dengan ketentuan yang diatur oleh Kementerian Agama Republik Indonesia tanpa ada perbedaan.

2. Apa Tugas Penyuluh Agama Islam

Jika mencermati pemaknaan terhadap penyuluh agama Islam di atas, maka secara umum dapat diketahui bahwa tugas penyuluh agama Islam adalah memberikan bimbingan dan konseling kepada masyarakat muslim tentang pokok-pokok ajaran agama Islam untuk keselamatan dunia dan akhirat. Secara formal bahwa tugas penyuluh agama Islam mengacu pada peraturan yang dikeluarkan oleh Kementerian Agama sebagai instansi yang diberi kewenangan untuk mengkoordinir dan mengaturnya.

Tugas tersebut adalah "melaksanakan bimbingan dan penyuluhan Agama dan Program Pembangunan melalui pintu dan bahasa Agama".4 Pelaksanaan bimbingan dan penyuluhan dilakukan dengan pendekatan sosio kultural masyarakat sebagai objek bimbingan akan tetapi menggunakan pendekatan-pendekatan yang agamis. Pendekatanpendekatan tersebut dimaksudkan agar masyarakat dapat dengan mudah memahami, memaknai, dan mengimplementasikan apa yang menjadi materi bimbingan dan penyuluhan.

Pendekatan dengan menggunakan bahasa agama tersebut dimungkinkan untuk lebih mudah tersosialisasikan, hal tersebut dikarenakan:

Agama Islam merupakan "system, prinsip kepercayaan kepada Tuhan yang Maha Pencipta dengan menjalankan perintah-Nya dan menjauhi larangan-Nya. Pendidik agama adalah pendidikan yang didasari pada ajaran agama wahyu yang diturunkan oleh Allah dengan tujuan mensejahterahkan dan memberikan kebahagiaan hidup dan kehidupan ummat manusia di dunia dan akhirat. Agama tersebut akan berfungsi sebagai kendali di dalam diri manusia dan mewarnai corak hidupnya jika dikembangkan melalui proses kendidikan yang sistematis secara bertahap berkesinambungan". 5

Sebagai sebuah sistem dan prinsip kepercayaan serta keyakinan pada sang Pencipta maka pelaksanaan tugas-tugas bimbingan dan penyuluhan agama Islam harus sedapat mungkin menyentuh aspek-aspek yang bersentuhan langsung dengan keyakinan yakni al Qalb (hati), al Aql (pikiran) dan an Nafs (keinginan). Jika ketiga aspek tersebut

\footnotetext{
${ }^{4}$ https://www.slideshare.net/dickindisav/tugas-dan-fungsi-penyuluh-agama-non-pns-2019

5 Nuryanis, Panduan Pendidikan Agama Islam Pada Masyarakat, (Jakarta: Direktorat Penamas Depag. RI., 2003) h. 6
} 


\section{Irfani}

ISSN 1907-0969 E ISSN 2442-8272

Volume 15 Nomor 2 Desember 2019

Halaman 84-98

http://journal.iaingorontalo.ac.id/index.php/ir

dapat tersentuh secara reaktif, maka apa yang disampaikan oleh para penyuluh agama Islam akan mudah dicerna dan diimplementasikan dalam kehidupan sehari-hari dan pada gilirannya berujung pada tujuan utamanya sejahtera dunia dan akhirat.

Jika dianalisa tugas memberikan bimbingan dan penyuluhan terhadap masyarakat yang diemban oleh para penyuluh agama Islam tersebut bukanlah merupakan tugas yang mudah untuk dilaksanakan, hal tersebut membutuhkan kemampuan yang mumpuni kaitan dengan kehidupan sosial budaya masyarakat dan uang lebih penting lagi adalah kemampuan pemahaman ajaran agama Islam. Dengan kemampuan tersebut para penyuluh dapat beradabtasi dan melakukan koseling penyuluhan keagamaan dengan baik.

3. Bagaimana Fungsi Penyuluh Agama Islam

Disamping tugas sebagaimana yang telah diuraikan di atas penyuluh agama Islam memiliki beberapa fungsi sebagai berikut:

a. Fungsi Informatif dan Edukatif

Penyuluh Agama Islam memposisikan dirinya sebagai da'i yang berkewajiban mendakwahkan Islam, menyampaikan penerangan agama dan mendidik masyarakat sebaik-baiknya sesuai dengan tuntunan Al-Qur'an dan Sunnah Nabi.

b. Fungsi Konsultatif

Penyuluh agama Islam menyediakan dirinya untuk turut memikirkan dan memecahkan persoalan-persoalan yang dihadapi masyarakat, baik persoalan persoalan pribadi, keluarga atau persoalan masyarakat secara umum. Penyuluh agama harus bersedia membuka mata dan telinga terhadap persoalan yang dihadapi oleh umat. Penyuluh agama menjadi tempat bertanya dan tempat mengadu bagi masyarakat untuk memecahkan dan menyelesaikan masalah dengan nasehatnya. Maka dalam hal ini penyuluh agama berperan sebagai psikolog, teman curhat dan teman untuk berbagi. Tetapi dari fungsi sebagai konsultatif tersebut belum sepenuhnya Penyuluh Agama menjadi tempat konsultatif masayarakat dalam memecahkan permasalahanya baik yang berhubungan dengan agama maupun dengan kehidupan sosialnya. Penyuluh Agama Islam baru berperan sebagai penyuluh yang berkedudukan sebagai pegawai negeri ( PNS) di Kementerian Agama.

c. Fungsi Advokatif

Penyuluh Agama Islam memiliki tanggung jawab moral dan sosial untuk melakukan kegiatan pembelaan terhadap umat/masyarakat binaannya terhadap berbagai ancaman, gangguan, hambatan dan tantangan yang merugikan akidah, mengganggu ibadah dan merusak akhlak. Fungsi advokatif penyuluh agama selama ini memang belum mampu seluruhnya dapat diperankan oleh penyuluh agama, dimana banyak kasus yang terjadi di kalangan umat Islam sering tidak dapat kita bela. Misalnya dalam kasuistik yang berhubungan dengan politik, keadilan sosial (penggusuran), bahkan sampai upaya pemurtadan yang 


\section{Irfani}

ISSN 1907-0969 E ISSN 2442-8272

Volume 15 Nomor 2 Desember 2019

Halaman 84-98

http://journal.iaingorontalo.ac.id/index.php/ir

berhubungan dengan perkawinan. Sehingga persoalan yang dihadapi tidak dapat diselesaikan dengan baik. ${ }^{6}$

Dengan memahami ke tiga fungsi tersebut para penyuluh agama Islam benarbenar dapat eksis di tengah-tengah masyarakat. Fungsi yang akan memberi ruang bagi mereka dalam melakukan konseling terhadap masyarakat muslim perihal membangun karakter dan etika keagamaan sebagai landasan utama dalam kehidupan sehari-hari baik dalam kaitannya dengan hablum minallah dan hablum minannaas.

\section{Faham Radikalisme}

Faham radikalisme dewasa ini merupakan faham yang menjadi bahan perdebatan nyaris disemua kalangan, apalagi sering dianalogikan dengan eksistensi agama Islam. Meskipun sebenarnya jika dimaknai secara umu radikalisme merupakan suatu pemahaman yang berpandangan secara tegas dan keras atau suatu faham yang menghendaki perubahan yang juga dilakukan secara tegas dan keras bahkan bisa mengarah kepada tindakan-tindakan kekerasan. Dengan pemahaman seperti itu, maka sebenarnya faham radikalisme dapat dilakukan oleh kelompok atau komunitas apapun di tengah-tengah masyarakat, apakah faham ini kemudian berafiliasi dengan ajaran agama tertentu atau organisasi masyarakat tertentu.

Berdasarkan pemikiran seperti itu maka asumsi sebenarnya faham radikalisme dapat disesuaikan dengan komunitas apa yang melekat pada faham tersebut, sehingga ketika bersentuhan dengan ajaran Islam maka sering disebut dengan Radikalisme Islam, sehingga bisa juga Radikalisme Politik, Radikalisme Ormas, semua tergantung pada tindakan masing-masing kelompoknya jika mengarah kepada tindakan kekerasan maka organisasi atau agama tersebut sering disebut dengan radikal.

Apa sebenarnya radikalisme sehingga membuat banyak orang termasuk pemerintah melalui Kementerian Agama berupaya kuat untuk memerangi faham tersebut. Istilah radikalisme sendiri sangat identik dengan individu atau komunitas muslim yang mempunyai pandangan dan sikap dalam kehidupan beragama dan politik yang senantiasa bertolak belakang atau kontradiksi dengan arus utama apakah itu pemerintah atau tradisi tertentu. Melalui cara pandang dengan indikator tertentu yang menjadi alat identifikasi, sehingga radikal sendiri adalah person atau kelompok tertentu yang memiliki keyakinan atau ideologi fanatisme kuat, sehingga dengan mudah menjastis orang yang tidak sepaham dengan pemikirannya, gerakan yang mengubah negara bangsa menjadi negara agama, memperjuangkan formalisasi syariat dalam agama.

${ }^{6}$ Departemen Agama, Panduan Tugas Operasional Penyuluh Agama Islam, (Jakarta: Direktorat Jenderal Bimbingan Agama Islam, 2004), h. 23 


\section{Irfani}

ISSN 1907-0969 E ISSN 2442-8272

Volume 15 Nomor 2 Desember 2019

Halaman 84-98

http://journal.iaingorontalo.ac.id/index.php/ir

Tindakan perubahan dan gerakan mengubah suatu negara menjadi negara agama yang dilakukan secara masiv tersebut kemudian dimaknai sebagai upaya jihad dalam menegakkan ajaran Islam. Istilah jihad ini bagi kaum radikal menjadi suatu keyakinan yang kuat, dengan mendasarinya pada ayat al Qur'an, contohnya dalam Surat al Furqon ayat 52 .

Terjemahan:

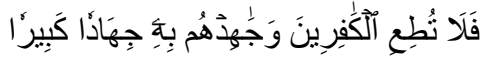

Maka janganlah kamu mengikuti orang-orang kafir, dan berjihadlah terhadap mereka dengan Al Quran dengan jihad yang besar.

Ayat tersebut menjadi landasan pembentukan keyakinan bagi kaum radikalis untuk mengharuskan mereka berjihad memerangi segala hal yang menurut mereka tidak sesuai dengan tuntunan syariat Islam. Mereka lebih memaknai kata jihad adalah suatu perang terhadap kejahatan sehingga mereka melakukannya dengan tindakan kekerasan. Mereka berasumsi bahwa berjihad untuk menegakkan kebenaran yang mereka fahami sebagai aktivitas di jalan Allah. Bagi mereka yang tidak mengikuti apa yang mereka fahami di anggap kafir meskipun sama-sama muslim, dan untuk itu harus diperangi dengan mengedepankan jihad kepada Allah.

Jika pemahaman seperti ini kemudian dibiarkan, tanpa ada bimbingan dan konseling dari para tokoh agama melalui moderasi beragama, maka pada akhirnya Islam yang rahmatan lil a-'alamin secara perlahan akan di usik dengan berbagai anggapan, misalnya menjadi agama yang radikal atau teroris.

Dalam kerangka itulah maka saat ini dibutuhkan para tokoh agama yang terkoordinir dan terkendali untuk senantiasa memberikan pencerahan dan cara-cara memahami konsep dasar beragama Islam dengan santun, berakhlakul karimah, damai dalam bingkai rahmatan lil 'alamiin. Oleh karena itu maka hadirnya penyuluh agama Islam menjadi sangat penting sebagai penyuluh langsung di tengah-tengah masyarakat muslim untuk melakukan pencegahan terhadap faham-faham sempalan radikalisme yang berafiliasi dengan Islam. Tentunya perlu dukungan baik secara kelembagaan, maupun kompetensi personal.

\section{METODE PENELITIAN}

Untuk mendapatkan gambaran yang faktual tentang subyek penelitian, maka peneliti akan menyajikan deskripsi riil yang sesungguhnya tentang kondisi lokasi penelitian dalam bentuk narasi, sehingga penelitian ini menjadi penelitian kualitatif deskriptif. Tampilan data yang dikehendaki dalam penelitian kualitatif deskriptif lebih bersifat pendeskripsian dan pemecahan masalah yang dilakukan dengan menarasikan sejumlah data dan peristiwa yang ada. Menurut Moleong bahwa Penelitian deskriptif berguna untuk mencari pemecahan masalah dengan menggambarkan peristiwa-persitiwa berdasarkan fakta atau bukti yang ada. ${ }^{7}$

${ }^{7}$ Moleong, Metodologi Penelitian Kualitatif. (Bandung: Remaja Rosdakarya, , L. J. 2005). h. 112 


\section{Irfani}

ISSN 1907-0969 E ISSN 2442-8272

Volume 15 Nomor 2 Desember 2019

Halaman 84-98

http://journal.iaingorontalo.ac.id/index.php/ir

Pengumpulan data dilakukan dengan wawancara mendalam, observasi dan dokumentasi. Wawancara ditujukan kepada para informan yakni para penyuluh agama Islam serta perwakilan masyarakat, sementara untuk observasi peneliti mendatangi langsung lokasi penelitian yakni di Kecamatan Suwawa Timur yang terdiri atas 9 Desa dan 8 orang penyuluh agama Islam. Penentuan informan dilakukan secara purposive yakni pemilihan yang didasarkan pada informan yang mengerti dan memahami masalah.

Analisis data dilakukan dengan 3 alur kegiatan yakni : 1) reduksi atau penyederhanaan data, 2) paparan data dan 3) penarikan kesimpulan. ${ }^{8}$

\section{PEMBAHASAN}

Deskripsi Lokasi Penelitian

Penelitian ini dilakukan di Kecamatan Suwawa Timur. Secara geografis merupakan salah satu kecamatan yang terdapat paling ujung timur Kabupaten Bone Bolango, Provinsi Gorontalo. Di Kemcanatan Suwawa Timur terdapat 9 Desa yakni; Desa Dumbaya Bulan, Desa Panggulo, Desa Pangi, Desa Poduoma, Desa Tilangobula, Desa Tinembe, Desa Tulabolo, Desa Tulabolo Barat, Desa Tulabolo Timur.

Berdasarkan informasi dari Badan Pusat Statistik Kabupaten Bone Bolango bahwa Kecamatan Suwawa Timur luas wilayah Kecamatan Suwawa Timur adalah 127,8 km². Dari 9 Desa sebagaimana yang telah dikemukakan di atas, maka desa yang terluas adalah Tulabolo Timur dengan 20,95\% atau 26,77 $\mathrm{km}^{2}$ dari luar Kecamatan Suwawa Timur, sedangkan desa yang memiliki luas terkecil adalah Desa Pangi 1,64\% atau 2,10 km². Adapun jumlah penduduk menurut agama dapat dilihat dalam tabel berikut:

Tabel 1.

Jumlah Penduduk Agama Islam dan Tempat Ibadah

\begin{tabular}{c|l|c|c}
\multirow{2}{*}{ No } & \multirow{2}{*}{ Desa } & \multicolumn{2}{|c}{ Jumlah } \\
\cline { 3 - 4 } & & Penduduk Muslim & Masjid \\
\hline \hline 1 & Tulabolo & 606 & 2 \\
\hline 2 & Dumbaya Bulan & 1142 & 2 \\
\hline 3 & Tilangobula & 600 & 2 \\
\hline 4 & Tulabolo Timur & 674 & 3 \\
\hline 5 & Tulabolo Barat & 529 & 2 \\
\hline 6 & Poduoma & 437 & 1 \\
\hline 7 & Panggulo & 319 & 1 \\
\hline 8 & Tinemba & 437 & 1 \\
\hline 9 & Pangi & 761 & $\mathbf{1 6}$
\end{tabular}

Sumber Data: Badan Pusat Statistik (BPS) Kabupaten Bone Bolango Tahun 2019.

${ }^{8}$ Miles, Matthew B. and A. Michael Huberman. Qualitative Data Analysis (terjemahan), (Jakarta : UI Press. 2007), h. 246 


\section{Irfani}

ISSN 1907-0969 E ISSN 2442-8272

Volume 15 Nomor 2 Desember 2019

Halaman 84-98

http://journal.iaingorontalo.ac.id/index.php/ir

Berdasarkan data tersebut diketahui bahwa $100 \%$ yakni 5505 jumlah penduduk muslim di Kecamatan Suwawa Timur Kabupaten Bone Bolango dengan Jumlah Tempat Ibadah sebanyak 16 Masjid. Data tersebut sangat mendukung untuk kegiatan bagi para penyuluh agama Islam melakukan kegiatannya dimana seluruh warga masyarakat Kecamatan Suwawa Timur beragama Islam serta memiliki tempat-tempat ibadah yang memadai.

Selanjutnya dalam paparan ini juga peneliti mengemukakan data jumlah penyuluh Agama Islam yang bertugas di Kecamatan Suwawa Timur Kabupaten Bone Bolango. Berdasarkan data yang diperoleh dari Kantor Urusan Agama Kecamatan Suwawa Timur bahwa jumlah penyuluh agama Islam berjumlah 8 orang sebagaimana dalam tabel berikut yakni:

Tabel 2

Data Penyuluh Agama Islam Di Kecamatan Suwawa Timur

\begin{tabular}{l|l|c} 
No & \multicolumn{1}{|c|}{ Nama } & Keterangan \\
\hline \hline 1 & Moh. Afandi Halubanga, S.H. & \\
\hline 2 & Reflianto Laposi, S.Fil.I & \\
\hline 3 & Anwar Mustapa Djailani & \\
\hline 4 & Ramliani Laposi, S.H.I. & \\
\hline 5 & Harlin K. Tangani & \\
\hline 6 & Nurhayati Abdullah & \\
\hline 7 & Sitriu Buhugo, S.Pd. &
\end{tabular}

Sumber Data: Kantor Urusan Agama Kecamatan Suwawa Timur Kabupaten Bone Bolango Tahun 2019

\section{Kegiatan Penyuluh Agama Islam Dalam Menangkal Faham Radikalisme di Kecamatan Suwawa Timur Kabupaten Bone Bolango}

Untuk mengetahui kegiatan penyuluh agama Islam dalam kaitannya dengan menangkal faham radikalisme di Kecamatan Suwawa Timur Kabupaten Bone Bolango, peneliti melakukan wawancara dengan para penyuluh agama Islam yang bertugas di Kecamatan Suwawa Timur Kabupaten Bone Bolango. Untuk jelasnya berikut ini beberapa hasil wawancara:

"dalam mencegah faham radikalisme banyak hal yang kami lakukan, misalnya membentuk kelompok-kelompok binaan seperti majelis taklim yang secara rutin dilakukan penyuluhan, bekerjasama dengan pemerintah Desa, disamping itu dimana setiap ada pertemuan di tingkat desa selalu dituangkan acara-acara yang berisi syi'ar Islam walaupun hanya beberapa menit, akan tetapi sudah dapat memberikan pencerahan kepada masyarakat yang hadir".

${ }^{9}$ Reflianto Laposi, Penyuluh Agama Islam Kecamatan Suwawa Timur Kabupaten Bone Bolango, Wawancara, Suwawa Timur, 3 Februari 2020 


\section{Irfani}

ISSN 1907-0969 E ISSN 2442-8272

Volume 15 Nomor 2 Desember 2019

Halaman 84-98

http://journal.iaingorontalo.ac.id/index.php/ir

Hal tersebut mendapatkan dukungan dari informan lainnya sebagaimana dikemukakan bahwa:

"memang tanggung jawab dalam memerangi faham radikalisme bukan pekerjaan mudah, tetapi juga tidak lantas kita mundur karena ini merupakan tanggungjawab bersama apalagi kami sebagai penyuluh, tentu ini akan memberikan tantangan tersendiri. Nah untuk itu cara kami adalah mendekati masyarakat muslim dari semua kalangan mulai dari anak-anak dibentuk taman-taman pengajian sambil juga memberikan pencerahan kepada mereka, dan juga membentuk majelis taklim yang secara rutin bergerak dalam bidang dakwah". ${ }^{10}$

Berdasarnya pernyataan dari kedua informan tersebut, dapat diperoleh informasi bahwa kegiatan penyuluh agama Islam secara umum dilaksanakan. Kaitan dengan upaya mencegah faham radikalisme, jika dicermat paparan di atas, bahwa tidak ada tindakan secara khusus yang berkaitan dengan faham radikalisme, akan tetapi kegiatan yang dilakukan sifatnya adalah gerakan dakwah, dimana muatan-muatan dakwahnya adalah memberikan pencerahan kepada warga muslim di Kecamatan Suwawa Tengah dalam kaitan dengan kehidupan agama Islam yang sesuai dengan tuntutan syari'atnya.

Hal tersebut dilakukan tentunya dapat menyentuh seluruh kalangan lapisan masyarakat mulai dari anak-anak sampai orang dewasa, dan pola pendekatannyapun berbeda-beda. Sebagai contoh khusus untuk anak-anak dan para remaja dibentuklah taman-taman pengajian yang muatannya tidak hanya bimbingan baca tulis al Qur'an, akan tetapi juga ada muatan-muatan kajian konsep dasar ajaran Islam yang mengarah kepada moderasi beragama. Sementara untuk kalangan dewasa dilakukan dengan gerakan dakwah yang bekerjasama dengan pemerintah Desa. Hal ini sangat penting untuk memberikan pemahaman kepada masyarakat dalam rangka mencegah agar tidak terpapar oleh faham-faham radikalisme.

Selanjutnya dalam wawancara dengan informan lainnya bahwa kegiatan yang terkait dengan upaya untuk melakukan pencegahan terhadap faham-faham radikalisme antara lain dapat dilakukan kerjasama dengan para pengurus masjid:

"tentunya untuk melakukan pencegahan faham-faham radikalisme adalah dengan memanfaatkan potensi keagamaan yang ada di setiap Desa, misalnya pengurus masjid ada Badan Ta'mirul Masjid dan juga Remaja Muda Masjid, mereka ini kita berdayakan, karena jika mengandalkan kami yang hanya berjumlah 8 orang dengan kondisi geografis yang sulit, maka tidak maksimal gerakan dakwah kami, oleh karena itu potensi keagamaan yang ada kami manfaatkan, contoh kerja sama dalam hal khutbah jum'at baik person maupun materinya, kegiatan-kegiatan seni budaya Islam lainnya juga memanfaatkan potensi generasi muda, dengan begitu

10 Moh. Afandi Halubanga, Penyuluh Agama Islam Kecamatan Suwawa Timur Kabupaten Bone Bolango, Wawancara, Suwawa Timur, 3 Februari 2020. 


\section{Irfani}

ISSN 1907-0969 E ISSN 2442-8272

Volume 15 Nomor 2 Desember 2019

Halaman 84-98

http://journal.iaingorontalo.ac.id/index.php/ir

kami mudah kerjasama dengan masyarakat sambil kami masukkan pencegahan masuknya faham-faham radikalisme". ${ }^{11}$

Berdasarkan beberapa penjelasan informan di atas, maka peneliti berkesimpulan bahwa penyuluh Agama Islam di Kecamatan Suwawa Timur Kabupaten Bone Bolango secara umum telah melakukan gerakan-gerakan pencegahan masuknya aliran atau faham radikalisme. Adapun pendekatan yang dilakukan lebih bersifat persuasif dengan memilih gerakan dakwah dengan pelibatan sejumlah potensi keagamaan yang ada dimasingmasing desa. Gerakan ini tentunya harus terus dilakukan secara dinamis dan berkesinambungan sehingga dengan begitu ruang gerak kelompok-kelompok radikal makin sulit untuk mendapatkan tempat di tengah-tengah masyarakat muslim pada umumnya, khususnya di Kecamatan Suwawa Timur Kabupaten Bone Bolango.

\section{Kendala dan Solusi Dalam Melakukan Penyuluhan Menangkal Faham Radikalisme di Kecamatan Suwawa Timur Kabupaten Bone Bolango}

Aktivitas keagamaan pada prinsipnya seperti aktivitas sosial lainnya memiliki berbagai kendala dalam melekatkan dengan kehidupan sosial kemasyarakata. Apalagi dengan tuntutan perkembangan saat ini dimana media sosial mempersempit ruang semesta alam ini sehingga informasi baik dan buruk sangat mudah terserap. Sehingga kegiatan-kegiatan yang dilakukanpun berhadap dengan sejumlah tantangan dan hambatan.

Kendatipun demikian bahwa persoalan penegakkan ajaran Islam dalam sejarah peradaban Islam sejak masa Rasulullah sampai dengan sekarang pasti akan beradahapan dengan berbagai tantangan. Bahkan Nabi sebagai utusan Allahpun dalam syi'ar Islamnya membutuhkan waktu yang cukup panjang. Oleh karena itu tantangan dalam penegakkan ajaran Islam disikapi sebagai sunnatullah dalam bentuk ujian ketangguhan kepada para pencerah ajaran Islam agar terus memasivkan kegiatan dakwahnya terutama dalam menangkal faham-faham sesat dan radikalis.

Kaitan dengan hal tersebut bagi penyuluh agama Islam di Kecamatan Suwawa Tengah Kabupaten Bone Bolango kaitannya dengan pencegahan faham radikalisme melalui gerakan-gerakan penyuluhan dan konseling keagamaan atau gerakan dakwah mengalami beberapa hambatan sebagai berikut:

"yang menjadi kedala gerakan penyuluhan dan konseling keagamaan antara lain adalah kehidupan sosial masyarakatnya dimana sebagian besar adalah petani dan penambang tradisional, sehingga untuk golongan remaja dan dewasa mengalami kesulitan untuk melakukan gerakan dakwah secara rutin, mereka beraktivitas dari pagi sampai sore bahkan sampai malam hari sehingga kesempatan untuk berdialog melakukan bimbingan hanya pada waktu-waktu tertentu. Misalnya kegiatan Jumatan seminggu sekali itupun tidak seluruh warga, pertemuan di Desa juga tidak semua warga dan itupun jarang dilaksanakan, solusinya yang dapat kami lakukan adalah memasifkan gerakan dakwah melalui taman-taman

${ }^{11}$ Ramliani Laposi, Penyuluh Agama Islam Kecamatan Suwawa Timur Kabupaten Bone Bolango, Suwawa Timur, 3 Februari 2020 


\section{Irfani}

ISSN 1907-0969 E ISSN 2442-8272

Volume 15 Nomor 2 Desember 2019

Halaman 84-98

http://journal.iaingorontalo.ac.id/index.php/ir

pengajian yang ada dan membuat kegiatan seperti khatam dan tadarusan sehingga memotivasi para warga untuk senantiasa mendukung dan momen kehadiran mereka dimanfaatkan untuk bimbingan dan penyuluhan keagamaan". ${ }^{12}$

Memperhatikan penjelasan di atas, maka dalam kaitan dengan tantangan yang hadapi oleh para penyuluh agama Islam untuk melakukan pencegahan terhadap masuknya aliran sesat atau faham-faham radikalisme khususnya di Kecamatan Suwawa Timur masih menemukan berbagai hambatan, terutama kaitannya dengan kondisi sosial kehidupan masyarakat. Hal ini merupakan permasalahan klasik yang hampir ditemui diseluruh wilayah di republik ini. Kebutuhan dan tuntutan hidup yang mengharuskan para warga untuk bekerja sesuai dengan profesinya masing-masing seolah sudah menjadi keharusan yang tidak terbantahkan. Oleh karena itu solusinya adalah kembali kepada para pencerah termasuk penyuluh agama Islam agar mampu beradabtasi dengan segala situasi sosial yang ada dengan begitu gerakan dakwah yang dilakukan dengan tujuan untuk memberikan pemahaman kepada masyarakat tentang beragama yang benar dapat dilaksanakan.

Hal senada juga disampaikan oleh informan berikut ini kaitan dengan berbagai tantangan tersebut:

"setiap profesi pasti ada tantangannya dan kami dilatih sesuai dengan profesi tersebut dengan mempertimbangkan segala resiko dan tantangan yang ada, oleh karena itu bagaimanapun tantangannya karena kegiatan kami ini bergerak dalam dakwah Islam maka kami akan terus menegakkannya apalagi dalam mencegah faham-faham radikalisme yang justru menyudutkan agama Islam. Memang di Kecamatan Suwawa Timur masih terdapat berbagai tantangan karena kondisi masyarakatnya dengan berbagai profesi tapi kami tidak kehabisan cara untuk mengahadapi tantangan itu semua, kami terus berdakwah secara perlahan, sedikit demi sedikit, harapannya jika apa yang dilakukan ini diberkahi oleh Allah maka kami yakin gerakan ini akan terus berkembang dan memberikan hasil yang lebih baik". ${ }^{13}$

Berdasarkan paparan tersebut maka peneliti dapat menyimpulkan bahwa kendatipun masih adanya tatangan kaitan dengan gerakan dakwah dalam menangkal masuknya aliran-aliran sesat atau faham-faham radikalisme, semua itu dapat teratasi dengan semangat dan daya juang para penyuluh agama Islam di Kecamatan Suwawa Tengah Kabupaten Bone Bolango. Sebagaimana juga disampaikan oleh informan laninnya berikut ini:

"bahwa bagi kami dalam menjalankan tugas ini ada 3 tanggungjawab yang kami emban, pertama tanggungjawab kepada Allah SWt., karena ini adalah gerakan dakwah, tanggungjawab kepada pemerintah karena secara organisasi kami

12 Anwar Mustapa Djailani, Penyuluh Agama Islam Kecamatan Suwawa Timur Kabupaten Bone Bolango, Suwawa Timur, 7 Februari 2020

${ }^{13}$ Sitriu Buhungo, Penyuluh Agama Islam Kecamatan Suwawa Timur Kabupaten Bone Bolango, Wawancara, Suwawa Timur, 7 Februari 2020 


\section{Irfani}

ISSN 1907-0969 E ISSN 2442-8272

Volume 15 Nomor 2 Desember 2019

Halaman 84-98

http://journal.iaingorontalo.ac.id/index.php/ir

dikoordinir oleh Kementerian Agama, dan tanggungjawab kepada masyarakat karena kami hidup dan berkecimpung di tengah-tengah masyarakat, oleh karena itu dengan tiga tanggungjawab ini semangat kami untuk terus menjadi pembimbing masyarakat yang bergerak dalam bidang keagamaan atau dakwah Islamiyah terus dilakukan, bagaimanapun bentuk tantangannya kami terus yakin suatu saat pasti akan memberikan hasil yang lebih baik bagi umat Islam". ${ }^{14}$

Memperhatikan penjelasan-penjelasan di atas maka secara umum peneliti berkesimpulan bahwa hambatan yang ditemui oleh para penyuluh agama Islam di Kecamatan Suwawa Timur Kabupaten Bone Bolango dalam menjalankan tugasnya sebagai pembimbing dan penyuluh agama Islam masih dapat diatasi.

Asumsi peneliti bahwa para penyuluh memiliki kesadaran yang tinggi serta tanggungjawab moral yang positif dalam menjalankan tugasnya, hal ini sangat penting sebagai dukungan moral bagi setiap penyuluh sehingga apapun tantangannya, bagaimanapun resikonya semua pasti dapat diselesaikan dengan baik. Pada akhirnya gerakan masiv dalam menangkal faham-faham radikalisme dapat terus ditindak lanjuti dengan kegiatan-kegiatan faktual dan nyata oleh para penyuluh agama Islam profesional di tengah-tengah masyarakat muslim pada umumnya, khususnya di Kecamatan Suwawa Kabupaten Bone Bolango.

\section{PENUTUP}

Berdasarkan penjelasan-penjelasan diatas, maka peneliti dapat berkesimpulan bahwa para Penyuluh Agama Islam di Kecamatan Suwawa Tengah terus melakukan kegiatan dalam menangkal atau mencegah faham radikalisme, melalui gerakan dakwa baik secara langsung maupun tidak langsung dengan membentuk majelis-majelis taklim, taman pengajian, serta bekerja sama dengan berbagai lembaga keagamaan dan pemerintah desa.

Dukungan dan kesadaran para penyuluh dalam menjalankan tugasnya menjadi sangat penting sebagai sebuah solusi disetiap hambatan yang ditemui dalam hal gerakan dakwah anti radikalisme di tengah masyarakat muslim Kecamatan Suwawa Timur Kabupaten Bone Bolango.

\section{DAFTAR PUSTAKA}

Akhtar, Shabir, 2002, Islam Agama Semua Zaman, Cet. 1, Jakarta: Pustaka Zahra

Departemen Agama, 2004, Panduan Tugas Operasional Penyuluh Agama Islam, Jakarta: Direktorat Jenderal Bimbingan Agama Islam. ., Al-Qur'an dan Terjemahnya, Jakarta; Surya Cipta Aksara, 1995.

Departemen Pendidikan Nasional, Kamus Besar Bahasa Indonesia, Ed. 3, Cet. 3, Jakarta: Balai Pustaka, 2007.

https://gorontalo.kemenag.go.id/artikel/29577/-

${ }^{14}$ Harlin K. Tangani, Penyuluh Agama Islam Kecamatan Suwawa Timur Kabupaten Bone Bolango, Wawancara, Suwawa Timur, 7 Februari 2020 


\section{Irfani}

ISSN 1907-0969 E ISSN 2442-8272

Volume 15 Nomor 2 Desember 2019

Halaman 84-98

http://journal.iaingorontalo.ac.id/index.php/ir

https://www.slideshare.net/dickindisav/tugas-dan-fungsi-penyuluh-agama-non-pns-2019

Moleong, 2005, Metodologi Penelitian Kualitatif, Bandung: Remaja Rosdakarya, , L.J

Miles, Matthew B. and A. Michael Huberman. 2007., Qualitative Data Analysis (terjemahan), Jakarta : UI Press.

Nuryanis, 2003, Panduan Pendidikan Agama Islam Pada Masyarakat, Jakarta: Direktorat Penamas Depag. RI.,

Umar dan Sartono, 1998, Bimbingan Penyuluhan, Bandung : Pustaka Setia,

www. Isna. Net/ library/ paper, 2003 